\title{
Corneal foreign bodies - Management the Ayurvedic way- A Case series
}

\author{
Case Report
}

\author{
Aiswarya V Nair ${ }^{*}$ \\ 1. SRF, Department of Shalakyatantra, \\ Govt Ayurveda College, Trivandrum, Kerala.
}

\begin{abstract}
Corneal foreign bodies are one of the most common and serious eye trauma cases reaching an ophthalmologist. Traditional medical systems like Ayurveda are imagined to have a very limited and obsolete role in managing acute traumatic presentations like corneal foreign bodies. Four cases of corneal bodies which were treated by ayurvedic medicines and procedures are being reported here as a case series. Each case had a type of foreign body embedded in their cornea and after removal of the foreign body by suitable methods, they were given ayurvedic topical as well as internal medicines and followed up at regular intervals. All cases healed without any complications. This case series shows that ayuveda can be effectively used to manage many corneal injuries and this area need to be explored on a clinical trial route to reach more valid conclusions.
\end{abstract}

Key Words: Eye foreign bodies, Cornea, Ayurvedic, treatment, Netrasalya, Research.

\section{Introduction}

Eye is the most important of all sense organs. Cornea, the transparent anterior part of eye is of vital significance as it refracts the incident light to provide the eye two third of its optical power. Cornea is especially vulnerable to trauma. Superficial foreign bodies (FBs) are found frequently in cornea and conjunctiva. Common foreign bodies include small particles of dust, steel, iron and other metals that are very likely to fly straight onto the cornea. This is especially common among drivers driving in dusty roads without helmets having visors, in persons involved in occupations like welding, metal industry, road works etc. without adequate protective eye gear. If corneal foreign bodies are not removed properly, they can progress to corneal ulceration due to exposure of cornea to infection by pathogenic organisms in the conjunctival sac (1). In case the organism is a virus, the resultant ulcer will be spreading in nature. Improper management of a corneal foreign body can result in development of corneal opacity, which can affect the vision of the patient. So prompt, correct diagnosis and management is absolutely essential in dealing with corneal foreign bodies.

Ayurveda, the ancient traditional medical system of India, is still widely practised in the Indian subcontinent. One among its eight classical branches,

\section{* Corresponding Author:}

Aiswarya V Nair

Thanal, VPS 354,

Vattavila, Thirumala P.O

Thiruvananthapuram,

Kerala- 695006, India

Email Id: aiswarya.v24@gmail.com
Shalakyatantra deals with ENT, ophthalmology, dentistry and diseases of head. In the current era Ayurveda is considered obsolete for managing acute presentations of diseases or in dealing with the aftermath of trauma. In case of a vital organ like eye, this notion is stronger. In classical Ayurveda texts, Sashalya netra lakshana (2), i.e. signs of eye with foreign body are described along with many methods to deal with foreign bodies entering the eye .This article is an effort to dispel this notion by presenting a case series of four cases of corneal foreign bodies that were successfully managed by ayurvedic modalities in the outpatient department (OPD) of Shalakyatantra department, government Ayurveda college, Trivandrum, Kerala over the month of July 2018.

\section{Case series}

Case 1

Case 1 was a male patient aged 28 years, a welder by profession, who felt foreign body sensation in his right eye (OD) while welding metal pieces in his workshop. He was not using protective goggles. He came to the outpatient department about two hours after the incident, with foreign body sensation, watering and pain in his right eye. On slit lamp biomicroscope examination of his eye under topical anaesthesia with fluorescein stain, a superficial metal FB was seen at 10 o' clock position midway between the centre and periphery of cornea. The FB was removed by using a hypodermic needle under local anaesthesia (Proparacaine $0.5 \%$ ophthalmic solution) by magnification through slit lamp biomicroscope. The rust ring was removed as much as possible. Then his eye was irrigated using Triphala decoction and a few drops of Durva ghritha was put in before loosely bandaging the eye. The patient was given Panchathiktaka decoction in the dose $90 \mathrm{ml}$ tds and T. Kaisoraguggulu in the dose 2 tds to be taken along with the decoction. 
The patient was advised to keep the bandage for 24 hours and report to the OPD after that. His eye pad was removed on the third day and the depression left from the FB had started healing rapidly and he was advised to continue using Durva ghritha and internal medicines for a few more days. On the $5^{\text {th }}$ day follow up when he was examined by slit lamp biomicroscope under fluorescein stain, he had a healthy cornea with no left over rust ring or abrasions. The pictures of OD under slit lamp examination on day 1 , day 3 and day 5 are given in figures 1 to 3 respectively.

Figure 1. Case 1- Day 1 OD slit lamp exam under fluorescein- depression after removing FB

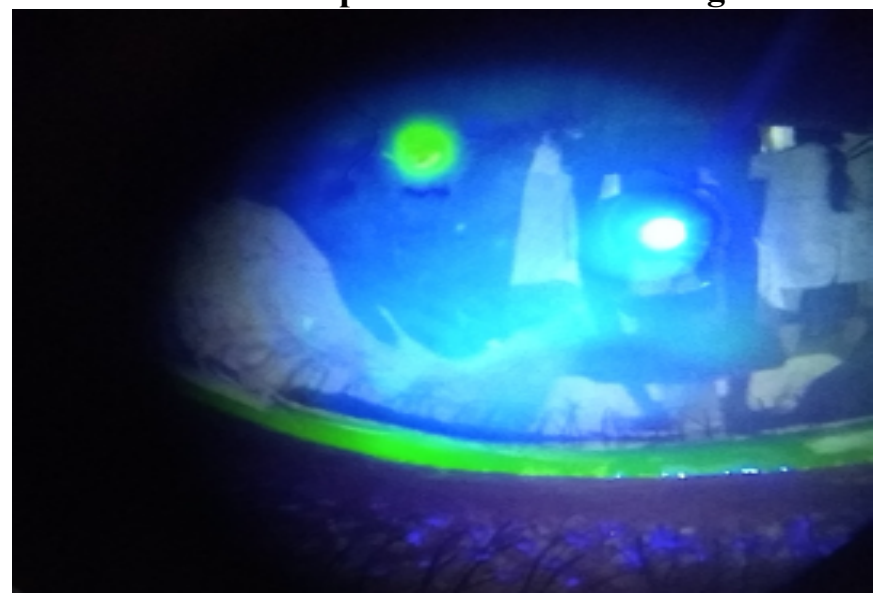

Figure 2. Case 1- Day 3- OD slit lamp exam under fluorescein- healing of the injury

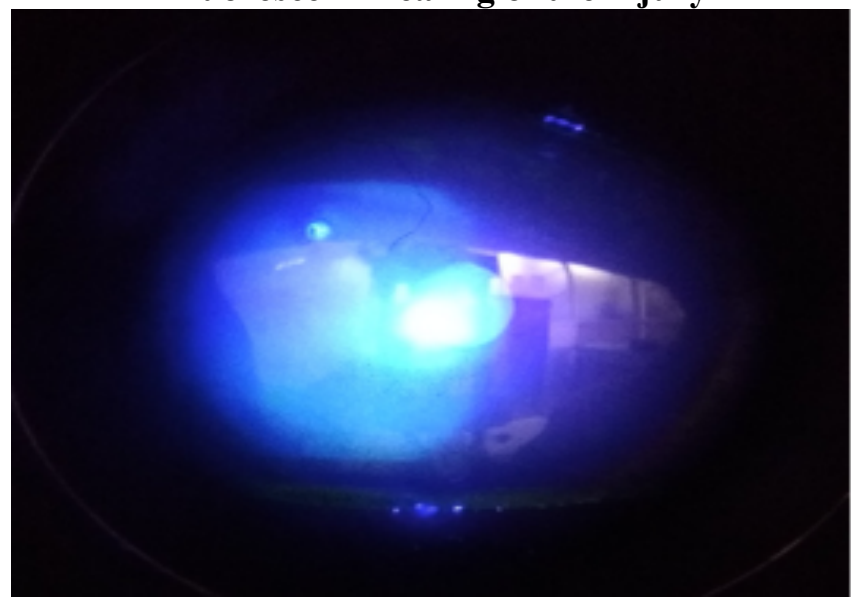

Figure 3. Case 1- Day 5 OD slit lamp exam under fluorescein- completely healed cornea

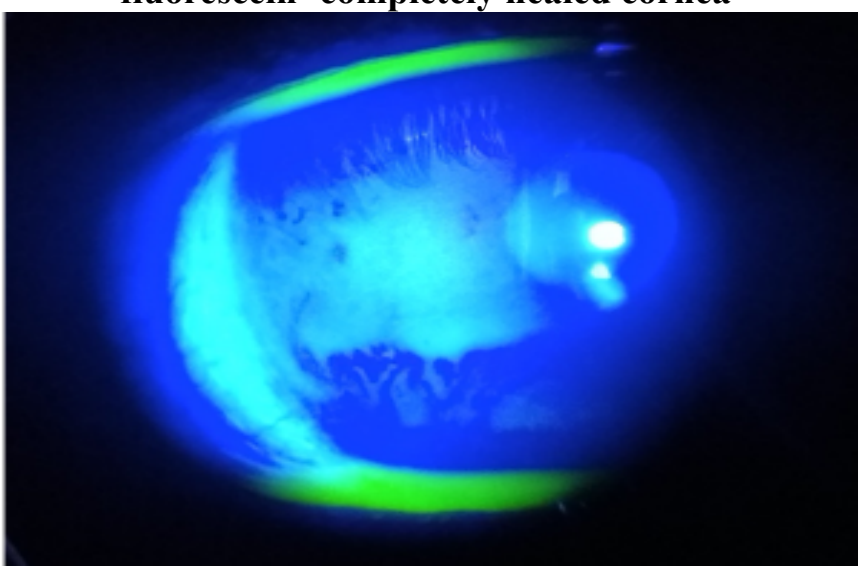

Case 2

Case 2 was a male patient aged 40 years, with a desk job, who while travelling on his motor cycle the previous day evening had felt that something flew into his left eye. On reaching home he had rubbed his eye and then washed his eyes with water. As his discomfort persisted into the next day, he came to the OPD. He had mild redness, foreign body sensation and discomfort in his eye along with watering. There was a corneal FB at 5 o' clock position about $5 \mathrm{~mm}$ from the centre of the cornea. It was an embedded dust particle. It was removed using a foreign body spud under local anaesthesia (Proparacaine $0.5 \%$ ophthalmic solution) by magnification through slit lamp biomicroscope. Then his eye was irrigated using Triphala decoction and few drops of Durva ghritha was put in before loosely bandaging the eye. He was advised Panchathiktaka decoction in the dose $90 \mathrm{ml}$ tds and T. Kaisoraguggulu in the dose 2 tds to be taken along with the decoction for 2 days. The patient was advised to keep the bandage for 24 hours and report to the OPD after that. His eye pad was removed on the third day and the eye examined under slit lamp biomicroscope. The abrasion left from the FB had healed completely.

\section{Case 3}

Case 3 was a male patient aged 36 years who was also in welding profession. He had discomfort and watering from his right eye since the previous day but had ignored it. He had used a protective glass while working. While presenting to the OPD he had redness, watering and mild pain in his right eye. He had a metallic particle at 2 o' clock position near the corneal periphery, embedded superficially. The FB was removed by using a hypodermic needle under local anaesthesia (Proparacaine $0.5 \%$ ophthalmic solution) by magnification through slit lamp biomicroscope. The rust ring was removed as much as possible. Then his eye was irrigated using Triphala decoction and few drops of Durva ghritha was put in before loosely bandaging the eye. He was advised Panchathiktaka decoction in the dose $90 \mathrm{ml}$ tds and T. Kaisoraguggulu in the dose 2 tds to be taken along with the decoction. The patient was advised to keep the bandage for 24 hours and report to the OPD after that. On the third day, after removing his bandage, rest of the rust ring was removed and he was he was advised to continue using Durva ghritha for a few more days. The internal medicines were continued for a week. At the one week follow up, the small depression left behind by the FB had healed completely with a very faint over scar that did not stain under fluorescein slit lamp biomicroscope examination.

\section{Case 4}

Case 4 was also a male, 45 years old, a daily wage labourer, who felt something flying into his right eye while breaking stones for road work. He had rubbed his eye and when his discomfort increased, tried washing his eyes with water. As his complaints persisted, he had come to the OPD about 4 hours after the incident. He had a superficial slightly hard dust particle at 6 o clock position and a $3 \mathrm{~mm}$ corneal 
abrasion extending from the FB due to rubbing of his eye. It was removed using a foreign body spud, under local anaesthesia (Proparacaine $0.5 \%$ ophthalmic solution) by magnification through slit lamp biomicroscope. Then his eye was irrigated using Triphala decoction and few drops of Durva ghritha was put in before loosely bandaging the eye. He was advised Panchathiktaka decoction in the dose $90 \mathrm{ml}$ tds and T. Kaisoraguggulu in the dose 2 tds to be taken along with the decoction. The patient was advised to keep the bandage for 24 hours and report to the OPD after that. His eye pad was removed on the third day he was advised to continue using Durva ghritha and internal medicines for a few more days. On the $5^{\text {th }}$ day follow up when he was examined under fluorescein stain slit lamp biomicroscope, the would had healed completely with no symptoms left.

\section{Results}

All four patients healed with no complications. Minimum time taken for complete healing of the injury was three days and maximum was seven days.

\section{Discussion}

This cases series is being reported with the objective to show Ayurveda in a new light that is in its capability in managing some of the acute and traumatic pathology occurring in eye, corneal foreign bodies.

Classical Ayurveda texts describe many methods for removal of foreign body from eye to be used as suitable to different situations including lekhana (scraping), blowing air, irrigation with water, removal with a clean cloth, etc. (3). In this case series, all cases were managed by the same protocol. After removal of the foreign body, washing the eyes with Triphala decoction is beneficial in two ways. It eliminates the left over foreign body particles and damaged tissues. Triphala consists of dried fruits of Terminalia chebula Retz., Terminalia bellerica (Gaertn.) Roxb., and Phyllanthus emblica L. It has antimicrobial and wound healing properties (4-5). Durva ghritha contains Durva (Cynodon dactylon (L.) Pers.) and Yashtimadhu (Glycyrrhiza glabra L.) in a ghee base. Glycyrrhiza glabra L. and Cynodon dactylon (L.) Pers. also have proven antimicrobial and wound healing activity (6-10). The internally prescribed decoction of Panchatikataka consists of Nimba (Azadirachta indica A. Juss.), Patola (Luffa acutangula (L.) Roxb.), Vyaghri (Solanum xanthocarpum Schrad. \& H. Wend1.), Guduchi (Tinospora cordifolia (Thunb.) Miers), Vasa (Adhatoda vasica Nees.) all of which have proven antimicrobial and anti-inflammatory properties (11-15). This formulation is considered antimicrobial and antiinflammatory in a broad spectrum. According to Ayurvedic literature, Panchathikataka is a group of five drugs having bitter taste. It is kapha-pitta dosha hara (pacifies kapha and pitta dosha), krimighna (antimicrobial action), as well as capable of depleting kleda (fluid accumulating due to increased permeability and defective tissue metabolism) etc. Through these pharmacological properties, it serves as both as wound healer and prevents complications due to possible infections. Kaisora guggulu is poly herbo-mineral formulation that is indicated in both wounds, ulcers and eye diseases. It is also anti-inflammatory in action. Consistent follow up is necessary to make sure that the wound is healing healthy with no complications.

All patients were males probably because they are more involved in situations that can result in corneal trauma like welding, chiselling etc. The healing time depends on the type as well as depth of the foreign body.

This being a case series has its own limitations and a randomized controlled trial with comparison of Ayurveda medicines against standard treatment followed in modern medicine will give more valid results. This is an attempt to show the healing capability of Ayurveda which is going global nowadays and to encourage further researches in this area.

\section{Conflict of interest}

There is no conflict of interest.

\section{References}

1. Sihota R, Tandon R. Parsons' diseases of the eye. $22^{\text {nd }}$ ed. New Delhi; Elsevier; 2016. 343-345p.

2. Tripathi I, Tripathi DS. Yogaratnakara. Reprint. Varanasi: Chaukhambha krishnadas academy; 2010: 799p.

3. Sharma S. Ashtanga Sangraha of Acharya Vaghbhata. Varanasi: Chaukhambha Sanskrit Series Office; 2012: 243p.

4. Peterson CT, Denniston K, Chopra D. Therapeutic Uses of Triphala in Ayurvedic Medicine. J Altern Complement Med. 2017; 23(8):607-614p.

5. Kumar, M., Kirubanandan, S., Sripriya, R. and Sehgal, P. Triphala Promotes Healing of Infected Full-Thickness Dermal Wound. Journal of Surgical Research. 2008; 144(1); 94-101p.

6. Biswas TK, Pandit S, Chakrabarti S, Banerjee S, Poyra N, Seal T. Evaluation of Cynodon dactylon for wound healing activity. J Ethnopharmacol. 2017;197;128-137p.

7. Abdullah S., Gobilik J., Chong K.P. In Vitro Antimicrobial Activity of Cynodon dactylon (L.) Pers. (bermuda) Against Selected Pathogens. In: Pogaku R., Bono A., Chu C. (eds) Developments in Sustainable Chemical and Bioprocess Technology. Springer; Boston; 2013.227-237p.

8. Irani M, Sarmadi M, Bernard F, Ebrahimi Pour GH, Shaker Bazarnov H. Leaves Antimicrobial Activity of Glycyrrhiza glabra L. Iran J Pharm Res. 2010; 9(4); 425-428p.

9. Gupta, V., Fatima, A., Faridi, U., Negi, A., Shanker, K., Kumar, J., et al. Antimicrobial potential of Glycyrrhiza glabra roots. Journal of Ethnopharmacology. 2008;116(2); 377-380p.

10. Biswas TK, Mukherjee B. Plant medicines of Indian origin for wound healing activity: a review. Int $\mathrm{J}$ Low Extrem Wounds. 2003; 2(1); 25-39p.

11. Mistry KS, Sanghvi Z, Parmar G, Shah S. The antimicrobial activity of Azadirachta indica, Mimusops elengi, Tinospora cardifolia, Ocimum sanctum and $2 \%$ chlorhexidine gluconate on 
common endodontic pathogens: An in vitro study. Eur J Dent. 2014; 8(2); 172-177p.

12. Raja Ratna Reddy Y, Krishna Kumari C, Lokanatha O, Mamatha S, Damodar Reddy C. Antimicrobial activity of Azadirachta Indica(neem) leaf, bark and seed extracts. Int. J. Res. Phytochem. Pharmacol. 2013; 3(1); 1-4p.

13. Singh B, Sharma RA. Anti-inflammatory and antimicrobial properties of pyrroloquinazoline alkaloids from Adhatoda vasica Nees. Phytomedicine. 2013; 20(5); 441-445p.
14. Shendge PN, Belemkar S. Therapeutic Potential of Luffa acutangula: A Review on Its Traditional Uses, Phytochemistry, Pharmacology and Toxicological Aspects. Front Pharmacol. 2018; 9; 1177p.

15. Pardhi P, Jain AP, Ganeshpurkar A, Rai G. Antimicrobial, Anti-oxidant and Anthelmintic Activity of Crude Extract of Solanum xanthocarpum. Pharmacognosy Journal. 2010; 2(11); 400-404p. 